\title{
Soil organic matter relationships with the geotechnical-hydrological parameters, mineralogy and vegetation cover of hillslope deposits in Tuscany (Italy)
}

\author{
Elena Benedetta Masi ${ }^{1}$ (D) $\cdot$ Gabriele Bicocchi $^{1,2} \cdot$ Filippo Catani $^{1}$
}

Received: 3 May 2019 / Accepted: 24 April 2020 / Published online: 10 May 2020

(C) The Author(s) 2020

\begin{abstract}
Soil organic matter (SOM) represents a main fraction of superficial soil characterized by a mechanical-hydrological behaviour different from that of the inorganic fractions. In this study, a method to measure the SOM content was applied to 27 selected sites in Tuscany (central Italy) characterized by the presence of soil types common in the region: cambisols and regosols. The method included the contribution from root fragments, which is a fraction often neglected or underestimated in measurements, in the overall estimate of the SOM content. The retrieved SOM contents were analysed considering the vegetation cover at the sites and the selected attributes of geological interest, such as geotechnical parameters and the mineralogical composition of the soils. The SOM normalized to the bulk samples ranges between 1.8 and $8.9 \%$ by weight, with the highest values of the SOM content being associated with vegetation cover classes of forest and woodlands without shrubs. The SOM values showed close relationships with the abundance of the finer fractions (silt and clay) of the soil samples, and considering the relations with geotechnical properties, moderate correlations were found with the plasticity index, unit weight and effective friction angle, overall demonstrating the importance of considering SOM when the geotechnical and hydrological properties of soils are evaluated.
\end{abstract}

Keywords Organic matter $\cdot$ Grain size $\cdot$ Soil mechanics $\cdot$ Vegetation cover $\cdot$ Geotechnical parameters

\section{Introduction}

Soil organic matter (SOM) is the fraction of soil consisting of plant and animal fragments at different stages of decomposition (Brady and Weil 1999). It has a fundamental role in the global carbon cycle, acting both as a $\mathrm{C}$ sink and source in the pedosphere in response to land use and climate changes. The structural, dimensional and chemical characteristics of SOM affect soil properties such as the soil structure, erodibility, water infiltration rate and holding capacity (Schulte 1995; Ding et al. 2002; Krull et al. 2004). It is known that the presence of organic matter in soil affects its engineering behaviour. However, a major part of the research on the influence of

Elena Benedetta Masi

elenabenedetta.masi@unifi.it

1 Department of Earth Sciences, University of Florence, Via G. La Pira 4, 50121 Florence, Italy

2 Institute of Geosciences and Earth Resources, CNR - National Research Council of Italy, Via G. La Pira 4, 50121 Florence, Italy organic matter has been carried out on highly organic soils, and relatively little is known about the mechanicalhydrological effects of low organic matter contents on soil behaviour. In relatively poor organic soil, increasing the organic matter content increases the optimum moisture content and decreases the maximum dry density of compaction and the corresponding maximum unconfined compressive shear strength (Holtz and Krizek 1970; Schmidt 1965; Franklin et al. 1973). Odell et al. (1960) found that increasing organic content is associated with increasing soil plasticity, but according to other researchers (Buckman and Brady 1969), as a low-plastic material, organic matter reduces the plasticity and cohesion of soils. Therefore, the presence of SOM should not be overlooked in the framework of hydrological and geotechnical studies when soil parameterisation and the analysis of the spatial distribution of soil characteristics are carried out.

The quantitative assessment of SOM fraction in soils can be significant for slope stability analysis because, as aforementioned, it has peculiar geotechnical features, and also because it could be used as potential indirect measure of the root biomass of the soil. The root systems of plants strongly affect the mechanical and hydrological behaviours of soils. As SOM 
mainly derives from growing in situ plants and residues of previous root systems (Bernoux et al. 1998; Malkawi et al. 1999), the measure of SOM could provide indications about root density and its spatial variations in soils, which is essential information to properly consider the influence of the belowground part of vegetation (the roots system) on slope stability.

Roots mainly control soil properties by (1) influencing soil suction: the root-water uptake reduces the soil moisture and consequently increases the soil matrix suction, inducing changes in the soil shear strength (Gan et al. 1988) and hydraulic conductivity (Ng and Leung 2012); (2) changing soil structures as the roots occupy the soil pore spaces (Scanlan and Hinz 2010; Scholl et al. 2014), retain water (Taleisnik et al. 1999) and release exudates (Grayston et al. 1997; Traoré et al. 2000); and (3) increasing soil shear strength, essentially the cohesion parameter (root reinforcement; e.g. Gray and Sotir 1996; Montgomery et al. 2000). It is worth noting that the presence of roots induces changes in the soil water retention curve (SWRC) through the process mentioned above, as the SWRC depends on soil pore size and its distribution (Romero et al. 1999; Ng and Pang 2011; Ng and Leung 2012).

The increase in soil strength due to roots has been widely studied through in situ and laboratory shear strength tests on rooted and not-rooted soils and through the measurements of the tensile strength of roots, so that the root reinforcement effect is quantitatively assessed for common species of plants (Genet et al. 2005, 2008, 2010; Hales et al. 2009, 2013; Hales and Miniat 2017; Anderson et al. 1989; Schmidt et al. 2001; Riestenberg 1994; Bischetti et al. 2005, 2009; Norris 2005; Zhang et al. 2012; De Baets et al. 2008; Burylo et al. 2011; Tosi 2007).

When physical models for slope stability studies are applied, usually, a unique value of root reinforcement-chosen in relation to the plant species present-is used for the entire area subject to the modelling (similar to other geohydrological parameters, e.g. Jia et al. 2012), although spatial variations in root density through the slope are known to exist. However, collecting data to obtain high-resolution models implies a considerable increase in time and costs. Indeed, root density evaluation today still represents a limit in including vegetational effects in slope stability models because the many methods that have been tested and used to quantitatively study root systems are highly time-consuming or, concerning the most advanced techniques, extremely expensive (Böhm 1979; Subedi et al. 2006; Dowdy et al. 1998; Costa et al. 2000; Pan et al. 1998).

The goals of this research are as follows: (1) to identify, set up and then apply an efficient method to evaluate SOM contents (fragments of roots included) in soil samples; (2) to analyse SOM variations in samples representative of the hillslope deposits of Tuscany; and (3) to inspect the dependence of SOM on vegetational cover, mineralogical composition, grain-size distribution and selected geotechnical parameters (dry unit weight, effective friction angle, saturated hydraulic conductivity and Atterberg limits) of the soils themselves.

\section{Materials and methods}

\section{Description of the study area}

Tuscany is a region in central Italy with an area of $23,000 \mathrm{~km}^{2}$ lying between latitudes $44^{\circ} 28^{\prime} 21^{\prime \prime} \mathrm{N}$ and $42^{\circ} 21^{\prime} 39^{\prime \prime} \mathrm{N}$. It is characterized by a heterogeneous morphology that varies from plains in the coastal areas and the main river valleys to hills and mountains in the innermost areas, which culminate in the main mountain chain in the region located at the northeastern margin, the Northern Apennines (Fig. 1). Hilly areas cover approximately two-thirds of the territory, while one-fifth is covered by the mountains and one-tenth by the plains and the valleys. The region is characterized by a diverse climate that follows the altitudinal and latitudinal gradients and varies based on the distance from the Tyrrhenian Sea. The hot summer Mediterranean climate in the coastal areas (Csa) progressively changes inland to warm-summer Mediterranean (Csb), humid subtropical $(\mathrm{Cfa})$, oceanic $(\mathrm{Cfb})$ and up to subpolar oceanic ( $\mathrm{Cfc}$ ) climates in the Apennine mountains (Lohmann et al. 1993; Hess and Tasa 2016; Rapetti and Vittorini 1986; Rapetti 2004). Total annual precipitation ranges from 530 to $2600 \mathrm{~mm}$, with heavy storms concentrated mainly in the autumn season (Fatichi and Caporali 2009). The sites of this study are subjected to the weather conditions of the $\mathrm{Csb}, \mathrm{Cfa}$ and $\mathrm{Cfb}$ climates, which are located in inland areas at altitudes between 211 and $963 \mathrm{~m}$ a.s.l.

From a geological point of view, Tuscany is occupied in its northeastern part by the Northern Apennine mountain chain. The chain (NW-SE trend and NE vergence) is characterized by a complex thrust-nappe structure (Carmignani and Kligfield 1990) and originated starting from the Upper Cretaceous, following the collision between the CorsoSardinian block and the Adria microplate. The subsequent emergence of the chain was also accompanied by the propagation of fault systems that determined the formation of the present ridges and depressions in the region (Alvarez et al. 1974; Kligfield 1979, Vai 2001; Bartolini 2003; Bortolotti 1992, Elter et al. 1975; Carmignani and Kligfield 1990). The region is mainly characterized by sandstone marls and calcareous marls in flysch facies in the northwestern part, sandstones and calcareous marls in flysch facies in the central and southern areas, and wide areas with colluvial and alluvial sediments. The bedrock of the sampling sites is composed of the flysch facies of sandstones, limestones and marls.

Due to topographic, lithological and climatic features, Tuscany is heavily affected by mass movements, with over 


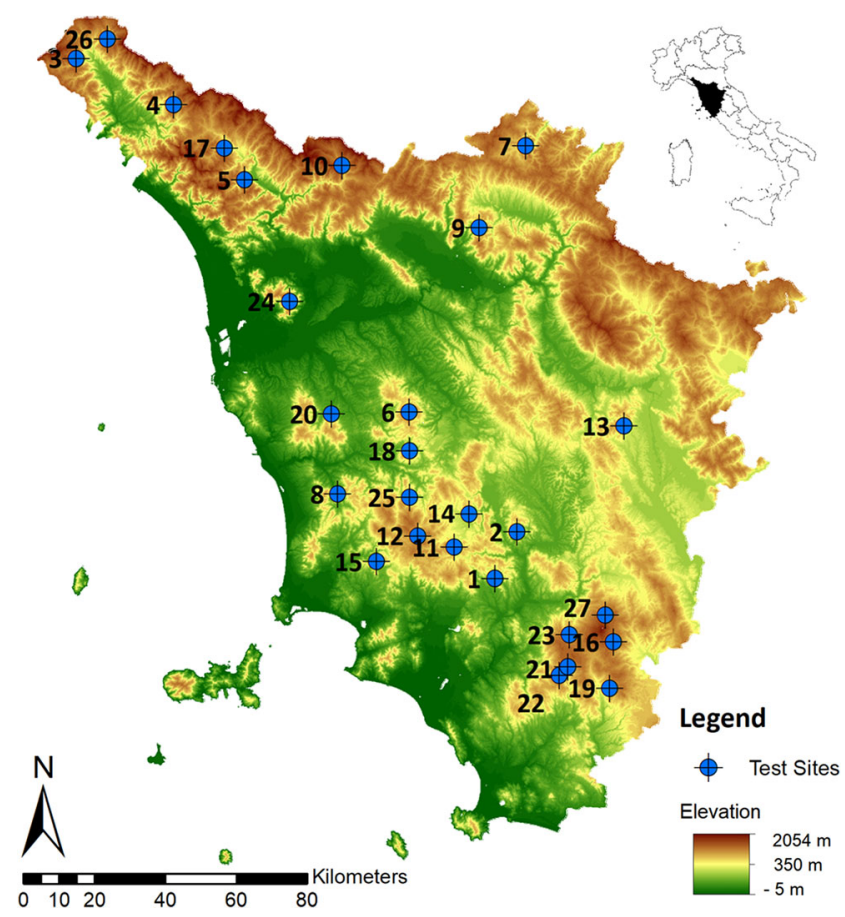

Fig. 1 Study area and investigated sites

90,000 active and quiescent landslides detected in the region, for a total area of $1817 \mathrm{~km}^{2}$ (Rosi et al. 2017).

The variety of altitudes, climate and outcropping lithotypes also furthered the establishment of heterogeneous vegetation in the territory: maquis, sclerophyllous woods (holms and cork oaks) and pinewoods in the coastal area; lowland and riparian woods (willows, poplars, alders and ashes) in the alluvial plains and along the river banks; thermophilic oak woods in the inland hills; and maritime pinewoods mixed with oak woods and mesophilic woods (Turkey oaks, chestnuts, beeches, firs, mixed woods of broad-leaf and conifers) in the mountain belt. Approximately, $50 \%$ of the region is covered by forests; the area occupied by "forest" and "other wooded lands", defined according to FRA2015 (2012), amounts to $1,151,539$ ha compared with an overall regional area of $2,299,018$ ha.

\section{Sample collection and vegetation cover classification}

Soil samples were collected at 27 selected sites in Tuscany (Fig. 1) in the period from November 2014 to September 2016. At each site, a characterization of the landscape vegetation elements was performed by means of photographic documentation and notes (about density of herbaceous plants, the interlocking of the crowns and eventual peculiarities), and a special classification for the type of vegetation observed was then arranged. This classification, derived from plant associations defined by Ellenberg (1965), aims to consider the different capabilities of plants in conditioning the hydraulic and geotechnical parameters of soils, which mainly depend on the density, length and diameter of plant roots. The defined classes are (1) closed forest with shrubs (CFS): trees with their crowns interlocking, shrubs are present, herbaceous vegetation is present (with different degrees of coverage) or absent; (2) closed forest without shrubs $(\mathrm{CF})$ : trees with their crowns interlocking, shrubs are absent, herbaceous vegetation is present (with different degrees of coverage) or absent; (3) sparse trees (ST): trees with most of their crowns not touching each other (at a maximum distance from each other of approximately of $10 \mathrm{~m}$ ), shrubs are present or absent, herbaceous vegetation is present (with different degrees of coverage) or absent; (4) shrubs (SH): vegetation mainly composed of shrubs, sporadic trees can be present, herbaceous vegetation is present (with different degrees of coverage) or absent; and (5) meadow (MD): herbaceous plants are predominant in the cover and sporadic woody plants (shrubs and trees) may be present. The MD and SC classes include all the landscapes where herbaceous vegetation or shrubs, respectively, constitute at least $75 \%$ of the total vegetation cover in terms of the occupied area. Therefore, the possible presence of trees or shrubs in areas mostly occupied by meadows or the presence of trees in shrub areas does not cause these areas to be classified as ST, CF or CFS. All the contexts in which canopies are not dense (i.e. where the sunlight can penetrate down to the ground) are classified as ST. To limit the overall number of classes in ST, CF and CFS classes, herbaceous vegetation can be either present or absent. However, since herbaceous vegetation can influence slope stability, it is important to specify in each case whether herbaceous plants are present or not and if they are, to what extent (e.g. continuous or discontinuous; for further details Bicocchi et al. 2015).

The sites were also classified according to the Corine Land Cover (CLC, "CORINE" is "COoRdination of INformation on Environment") third-level cartography updated to 2012 100-m resolution (CLC 2012- Land Monitoring Service; the third level of CLC cartography differentiates types of vegetation constituting the land cover) and to the world reference base (Wrb) for soil resources maps by the European Soil Data Centre (European Soil Database v2; Tóth et al. 2008).

For the laboratory analysis (organic matter content, mineralogical composition and acid test for carbonate minerals), an aliquot of $\sim 2 \mathrm{~kg}$ of soil was collected by means of hand augers within a maximum depth of $60 \mathrm{~cm}$ (the most between 45 and $50 \mathrm{~cm}$, for a pair of samples at $60 \mathrm{~cm}$ ), and the shallowest $10 \mathrm{~cm}$ of layers covered by vegetation was discarded. All samples were taken within the horizon A defined by USDA (United States Department of Agriculture, e.g. Owens and Rutledge 2005) and a classification of the surveyed soils is available in Table 1 (USCS field) for each sampling site. Such a sampling depth range is above of the point where generally shallow landslides failure planes are located ( $\sim 1.5 \mathrm{~m}$ of depth; Dietrich et al. 2007), and thus, the materials analysed are representative of those involved in shallow landsliding. Indeed, 


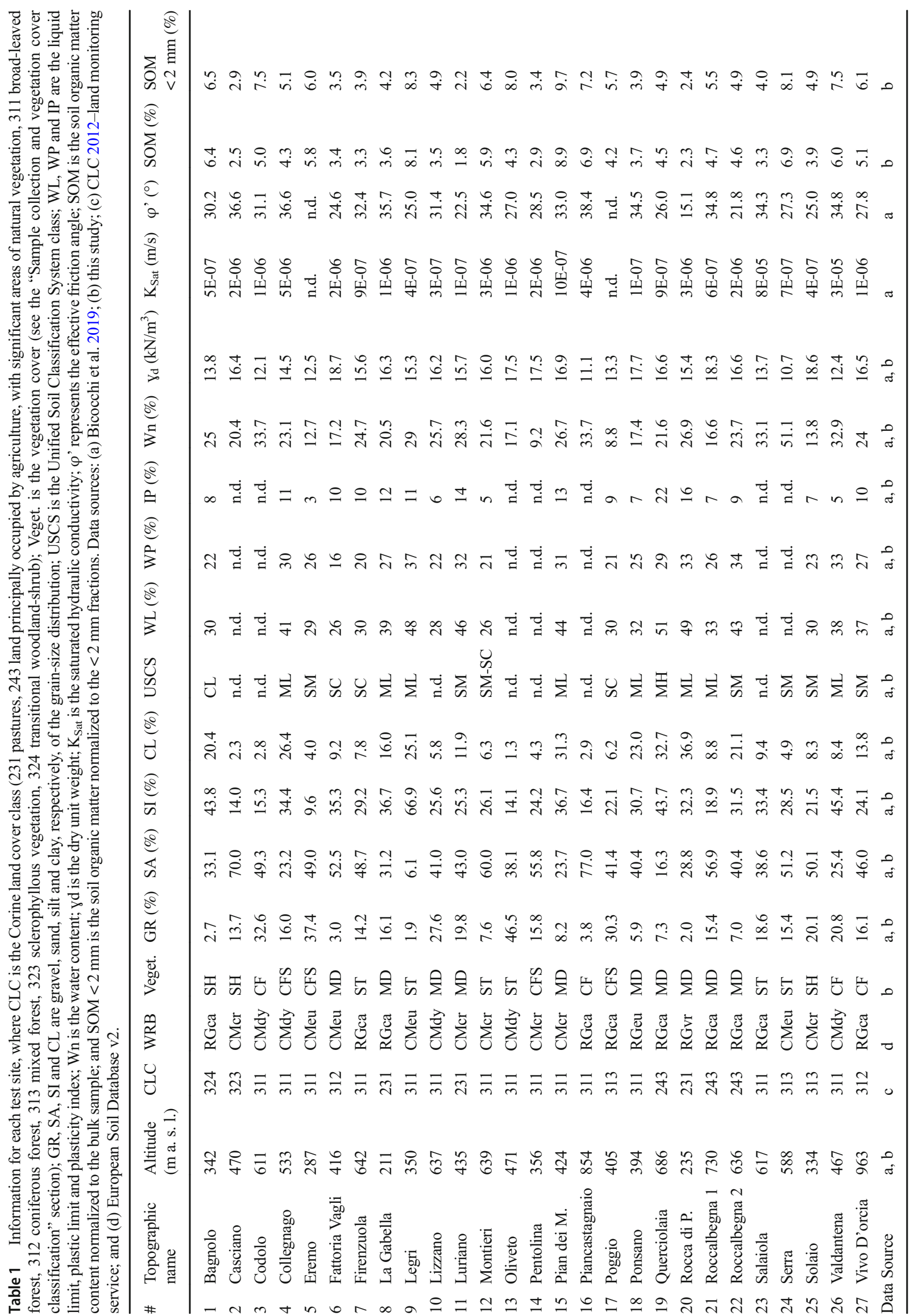


much part of the sampling area of the study is prone to that kind of landslides (Rosi et al. 2017; Tofani et al. 2017; Trigila et al. 2013; Convertino et al. 2013).

The samples were temporarily stored in non-sealed plastic bags for transport and then dried at an environmental temperature of $20^{\circ} \mathrm{C}$. At the same sites, another aliquot of approximately $2 \mathrm{~kg}$ and two hollow punches was collected by Bicocchi et al. (2019) to determine the following index properties: grain-size distribution, natural, dry and saturated unit weight, and the Atterberg limits, while the internal friction angle of the soil under natural conditions was determined by means of the borehole shear test (BST; Lutenegger and Hallberg 1981) and the saturated hydraulic conductivity (hereafter $\mathrm{k}_{\mathrm{sat}}$ ) measured by means of the constant head well permeameter Amoozemeter (Amoozegar 1989).

The choice of sampling the materials for the SOM evaluation in a small range of depths was motivated by two reasons: to avoid a further potential factor of variation in the SOM value, and to measure the latter on soil volumes and depths comparable with those used in the BST field testing (more details on BST tests are available in Bicocchi et al. 2019).

\section{Laboratory analyses}

For each sample of soil, in this study, the following parameters were evaluated: (1) organic matter content; (2) mineral phase recognition via X-ray powder diffraction; and (3) acid test for carbonate minerals. In addition, the following parameters determined on the samples by Bicocchi et al. (2019) were considered for this study: (1) grain-size distribution; (2) dry unit weight $\gamma_{\mathrm{d}}$; (3) Atterberg limits; (4) saturated hydraulic conductivity $\mathrm{K}_{\mathrm{Sat}}$; and (5) effective friction angle $\varphi$ '. Analyses were performed according to the ASTM (American Society for Testing and Materials) recommendations (ASTM D42263 2007; ASTM D2217-85 1998; ASTM D-4318 2010).

The grain-size distribution, dry unit weight and Atterberg limits for two samples not analysed by Bicocchi et al. (2019) were also determined in this study.

\section{Organic matter content determination}

The most commonly used methods for SOM determination are the Walkley-Black (WB) or "wet oxidation procedure", which determines the SOM by quantifying the oxidizable carbon in the soils through the reaction with the dichromate ion $\left(\mathrm{Cr}_{2} \mathrm{O}_{7}{ }^{2-}\right.$; Magdoff et al. 1996). The WB is a tolerably accurate and routinely used method but is highly time-consuming, expensive and potentially very polluting. A less frequently used procedure is loss-on-ignition (LOI). However, the LOI is a valid alternative to the WB method in terms of results since it is simpler, less expensive and does not require the use of acids (Salehi et al. 2011). When using the LOI procedure, the SOM is estimated by measuring, after a preliminary drying procedure to remove atmospheric moisture, the loss of weight in the samples after exposure to elevated temperatures in a muffle oven (Cambardella et al. 2011). Commonly used temperatures range from 300 to $550{ }^{\circ} \mathrm{C}$ (Salehi et al. 2011). For this research, a modified LOI (concerning sample preparation) at $550{ }^{\circ} \mathrm{C}$ was adopted.

The samples were exposed to air for at least 1 week to obtain natural drying. Each sample was weighed, minced and sieved (passing at Ø-2 mm). Large roots retained in the sieve were withdrawn and re-added to the passing fraction (sediments and small roots) that was analysed to determine the organic matter contents. The longest roots were cut into $\sim 1.5-\mathrm{cm}$-long fragments. In the standard procedure, the material retained by the 2-mm sieve is discarded so that the largest roots (the contribution of which is of interest for this research) would not be included in the analysis. Representative samples (of the sieved materials) of approximately $20 \mathrm{~g}$ were exposed to $40{ }^{\circ} \mathrm{C}$ for $2 \mathrm{~h}$ and to $100{ }^{\circ} \mathrm{C}$ for $24 \mathrm{~h}$. Then, two aliquots of approximately $5 \mathrm{~g}$ were withdrawn from the dried subsamples. Two fractions for each subsample were analysed at the same time for a comparison related to the repeatability of the procedure and to mitigate any nugget effects (the organic matter content in a sample is expressed by an average of the results of the two fractions). The 5-g subsamples placed in sterilized quartz-fibre crucibles were then exposed to $550{ }^{\circ} \mathrm{C}$ for $2 \mathrm{~h}$. In our case, the adoption of the highest temperature among those commonly used is the result of the need to consume the large roots present in the samples, which are more resistant to calcination compared with the organic matter of smaller size that is usually measured with LOI. The samples were then weighed; the measured loss of weight corresponded to the organic matter that was transformed in volatiles and lost during combustion. The subsequent step is represented by chemical oxidation: the two calcined residues were mixed with $5 \mathrm{ml}$ of hydrogen peroxide $(30 \% \mathrm{v} / \mathrm{v})$ and Milli-Q® water solution in beakers covered with parafilm ${ }^{\circledR}$ and then left to react until the end of the reaction (which is usually achieved in 3 to 4 days on average). After the evaporation of the remaining solution (exposure to $70^{\circ} \mathrm{C}$ for $2 \mathrm{~h}$ and $110{ }^{\circ} \mathrm{C}$ for $24 \mathrm{~h}$ ), the loss of mass in percentage was evaluated. The content of the organic matter in the sample expressed as a percentage of the mass is equal to the sum of the losses measured in the two processes (ignition and oxidation). Samples analysed as exposed are subjected to two different processes: they are first calcined and then oxidized. The oxidation process had the purpose of oxidizing the residual organic carbon (essentially constituted by roots, the organic matter of largest dimension present in the samples) not burnt during calcination. Therefore, the percentages of the organic matter content of the samples had to be the result of the sum of weight losses measured in the two procedures. However, because the weight losses due to oxidation were comparable with the accuracy of the process (valued at $0.5 \%$ considering the weighing scale sensitivity and the possible losses of materials during processing), the 
organic matter content is detected based on calcination results only. That fact represents, however, a notable outcome, as it proves that in calcined samples, there is no detectable organic matter. All the samples were subjected to both processes. The accuracy of this organic matter content analysis is $0.5 \%$ (so comparable with those of the grain-size distribution analysis).

The distribution of the SOM with respect to the grain size of the inorganic fractions was also studied on seven selected samples. The samples were selected so that all the range of measured SOM was well represented, choosing samples with the lowest amounts of SOM, with intermediate amounts and highest amounts. The organic matter was evaluated on the fraction constituted by gravel and sand and on the fraction constituted by silt and clay using the LOI-modified method and the oxidation as a control.

\section{Mineral phase recognition and inorganic carbon detection}

X-ray diffraction was performed on samples powder sieved to $<63 \mu \mathrm{m}$ using a Philips PW 3710 instrument equipped with an $\mathrm{X}$-ray $\mathrm{Cu}$ anticathode tube and filter in graphite at the Department of Earth Sciences, University of Florence. The interval $(2 \theta)$ from $5^{\circ}$ to $70^{\circ}$ was analysed, with an angular velocity of $2 \% \mathrm{~min}$, for an overall duration of $35 \mathrm{~min}$ for each analysis. Alimentation is settled to $20 \mathrm{~mA}$ with a potential of $40 \mathrm{kV}$, exploring a d-space interval of 1.34 to $17.66 \AA$. X'Pert PRO software was used to remotely control the instrument and to refine the diffractograms generated by the analyses to recognize the mineralogical phases present in the samples.

Under the P-T conditions adopted for the determination of organic matter contents ( 1 bar, $550{ }^{\circ} \mathrm{C}$ ), calcite is known to start degrading, releasing $\mathrm{CO}_{2}$ (Fisler and Cygan 1998). If present, in addition to the organic carbon, inorganic carbonate thermal degradation may have contributed to the loss of weight detected in the analysed samples. To avoid a misleading result owing to SOM contents, the presence of inorganic carbonates must be ruled out. To detect the presence of carbonate minerals, XRPD (X-ray powder diffraction) data were employed. However, since small amounts $(<1 \%)$ of carbonate minerals are not detectable in XRPD spectra, a second control was performed by using a $3 \% \mathrm{w} / \mathrm{w} \mathrm{HCl}$ solution on dried, minced and sieved $(0.075 \mathrm{~mm})$ samples. Each sample was classified based on the intensity of the reaction with respect to the $\mathrm{HCl}$ solution as "non-reactive" (NR), "poorly reactive" (PR), "reactive" (RE) or "highly reactive" (HR).

\section{Results}

All the information obtained from classifications and measurements for each surveyed site are summarized in Tables 1 and 2.

\section{Grain-size distribution and geo-hydrological parameters}

The particle-size compositions of the samples were analysed considering the 4 classes defined by AGI (1963): "gravel" (d $>2 \mathrm{~mm}, \mathrm{GR})$, "sand" (2 mm $<\mathrm{d}<0.06 \mathrm{~mm}, \mathrm{SA})$, "silt" $(0.06 \mathrm{~mm}<\mathrm{d}<0.002 \mathrm{~mm}, \mathrm{SI})$ and "clay" ( $\mathrm{d}<0.002 \mathrm{~mm}$, $\mathrm{CL}$ ). The materials of the deposits analysed are classified for the most part as silt or silty sand (ML and SM, respectively, in USCS classification; Wagner 1957). Their mean grain-size distribution can be represented by the closed geometric mean, which is an appropriate parameter to evaluate the barycentre of the distribution for compositional data (e.g. Aitchison 1982). The closed geometric mean $\mathrm{g}_{c}$ or "centre" is calculated as follows:

$\mathrm{g}_{c}=\mathrm{C}\left(\mathrm{g}_{1}, \mathrm{~g}_{2}, \ldots, \mathrm{g}_{\mathrm{D}}\right)$,

where $\mathrm{C}$ denotes the closure operation, which is defined for any vector of $\mathrm{D}$ real positive components $z=\left[z_{1}, z_{2}\right.$, $\left.\ldots, z_{D}\right]$, to the constant $k$, as follows:

$\mathrm{C}(\mathrm{z})=\left[\frac{k \cdot z_{1}}{\sum_{i=1}^{D} z_{i}}, \frac{k \cdot z_{2}}{\sum_{i=1}^{D} z_{i}}, \ldots, \frac{k \cdot z_{D}}{\sum_{i=1}^{D} z_{i}}\right]$

and $g$ is the geometric mean. For our dataset, the centre is $\mathrm{GR}=13.5 \%, \mathrm{SA}=44.6 \%, \mathrm{SI}=31.2 \%$ and $\mathrm{CL}=10.8 \%$. The grain-size distribution of each sample is represented in Fig. 2 by a ternary plot, in which the silt and clay fractions were combined, and by a quaternary plot.

The dry unit weight ranges from 10.7 to $18.7 \mathrm{kN} \mathrm{m}^{-3}$ with a mean of $15.4 \mathrm{kN} \mathrm{m}^{-3}$. Concerning the Atterberg limits, the plasticity index (IP) of the samples varies from a minimum of $3 \%$ to a maximum of $22 \%$. The two highest IP values $(22 \%$ and $16 \%$ ) are both related to high liquid limit (LL) values (51\% and $49 \%$, respectively). Similarly, the lowest IP value (3\%) is related to a low LL (29\%, one of the lower values of the dataset). Values range from 26 to $51 \%$ for the LL and 16$37 \%$ for the plastic limit (PL). The $\varphi$ ' values measured in situ range from $15^{\circ}$ to $38^{\circ}$, while the saturated hydraulic conductivity $\left(\mathrm{K}_{\mathrm{Sat}}\right)$ varies from $2 \cdot 10^{-7}$ to $8 \cdot 10^{-5} \mathrm{~m} \mathrm{~s}^{-1}$.

\section{Soil mineralogical composition and vegetation cover}

Regarding soil mineralogical phases, with very few exceptions, mica, quartz and clay minerals are detected in most of the samples; other common phases are plagioclases (22 out of 27 samples), k-feldspar (15 samples) and calcite (10 samples). Uncommon phases detected in one or at most in two samples are hornblende, chrysotile, bassanite, goethite, haematite and gypsum. In the soil samples, the clay fraction ranges from 1 to $37 \%$. Some samples (5) are selected with respect to this range (that is, choosing samples with the lowest amount of clay, with 
a modest amount and with the highest amount of this fraction) to identify clay minerals present in the investigated soils. In all samples, illite, kaolinite and chlorite-vermiculite were detected; in four samples, illite-montmorillonite was identified, and in three samples, chlorite was identified.

According to the vegetation cover classification arranged for this study, most of the investigated sites are characterized by a predominant presence of meadow with, eventually, very sporadic shrubs and trees. Indeed, approximately $37 \%$ of the sites are classified as MD. The remaining sites are classified as follows: $22 \%$ SP, $14 \%$ CFS, another $14 \%$ as CF and an $11 \%$ SH. Based on the CLC 2012 classification instead, more than half $(52 \%)$ of the sites are broad-leaved forest (311). If all the classes representing the wooded area are merged (i.e. merging the classes $311,312,313,323$ and 324 so that no difference is made between the types of wood), $78 \%$ of the sites have a vegetation cover constituted mainly by some type of wood, and only $22 \%$ is represented by pasture or cultivated lands $(231,243)$.

\section{Soil organic matter content}

The values of organic matter content are reported in Table 1. SOM contents, expressed as a percentage of the fine fraction of each sample (i.e. finer than $2 \mathrm{~mm}$ : sand, silt and clay), vary from $2.2 \%$ (site 11 ) to $9.7 \%$ (site 15 ) with a mean of $5.4 \%$ and a median of $5.1 \%$. The percentages of organic matter contents normalized to the bulk samples (including the fraction $>$ $2 \mathrm{~mm}$, i.e. gravel) range instead from 1.8 (site 11) to $8.9 \%$ (site 15); the mean value is $4.6 \%$ and the median is $4.2 \%$. Figure 3 shows SOM in the particle-size fractions of the samples (see the "Organic matter content determination" section, Fig. 3). The organic matter tends to be more abundant in the finer fractions. Indeed, in each of the 7 samples chosen for this test, the measured SOM content was higher in the fraction finer than $75 \mu \mathrm{m}$. The highest difference is in the sample from site 17 in which the SOM content of the finer fraction is twice that of the coarser fraction. Differently, in the sample from site 9 , the amount of the organic matter of the fractions is almost equivalent. On average, the organic matter content in the finer fraction is four-thirds of the content of the coarser fraction.

\section{Discussion}

\section{Relationships of the SOM content with grain-size distribution and vegetation cover}

The ranges of SOM values detected in this study are comparable with those generally found in mineral soils. A meaningful comparison can be performed with respect to the 2009 LUCAS (Land Use/Land Cover Area Survey, Tóth et al. 2013) database on the chemical and textural characteristics 
Fig. 2 Quaternary plot and ternary plot of the grain-size distributions of the samples. In the ternary plot, the silt and clay fractions are combined

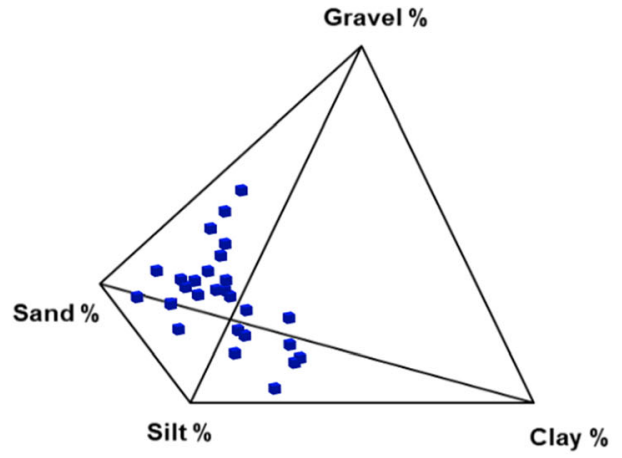

of topsoils ( $0-30 \mathrm{~cm}$ from the top) in Europe from 22,000 soil samples. In addition to the other properties of soils, the soil organic carbon (SOC) was also evaluated (with respect to the standard ISO 10694:1995, which implies air temperature dehydration and $2 \mathrm{~mm}$ sieving for samples, Jensen et al. 2003). The SOM/SOC ratio lies between 1.4 and 3.3 in most soils (Rasmussen and Collins 1991). Commonly, SOM is estimated from the SOC concentration by applying a conversion factor of 1.724, but according to a review on the argument by Pribyl (2010), a factor of 2 , based on the assumption that organic matter is $50 \%$ carbon, would be more accurate. The European map of estimated (based on the measured contents) SOC by Tóth et al. (2013) shows for Tuscany a range of values from 0.5 to $5 \%$ by weight. Applying the SOM/SOC conversion factor of 2 to our SOM values, the organic carbon content in our samples ranges from 1.1 to $4.8 \%$. Therefore, the measured values are in good agreement with those by Tóth et al. (2013).

Vegetation cover types and grain-size distributions of the soils can influence each other. In addition, they both control the abundance of SOM. Vegetation affects the soil texture through mechanical and chemical actions. The mechanical influence is mainly due to the action of growing roots that favour

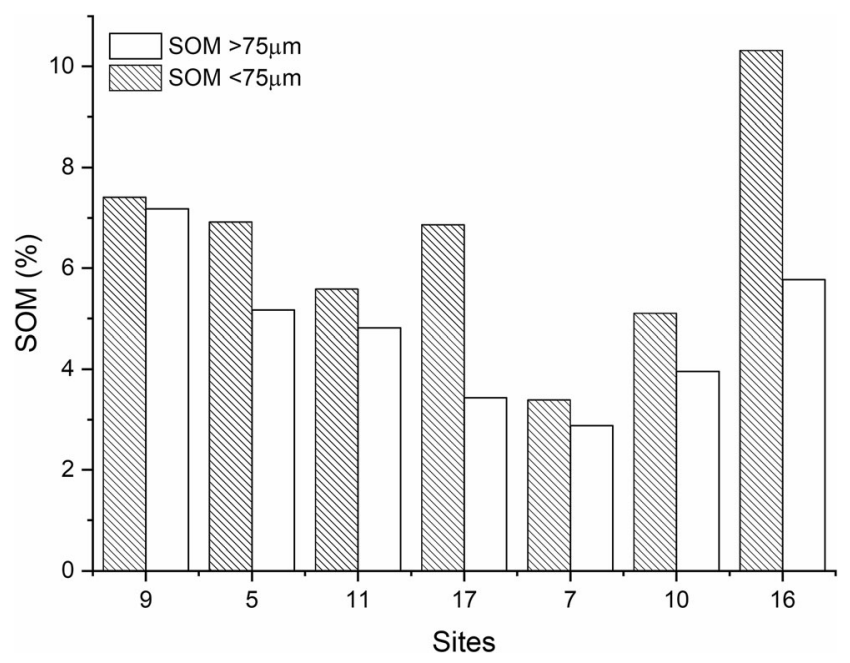

Fig. 3 Distribution of SOM (soil organic matter) in the fractions smaller or larger than $75 \mu \mathrm{m}$ of 7 selected samples the physical disintegration of soils and to the retention of finer grains by the smaller roots. Regarding the chemical effects, root exudates and chemical element interchanges between the soil and roots determine the establishment of certain chemical conditions, which can favour the chemical decomposition of some minerals or the formation of clay minerals such as smectite (Barbieri 1981; Carnicelli et al. 1997; Certini et al. 2003; Egli et al. 2008). Furthermore, plants generally have strict needs for permeability of the substrate in which they grow. Since soil permeability is also dependent on the grain-size distribution, with the analysis of the grain-size distribution/vegetation cover relation, some trends could be detected. Sites classified as ST seem to localize in soils with an abundant sand fraction (with the exclusion of site 9, which is a ST site with a grain-size distribution almost totally represented by SI and CL), while meadow is the vegetation cover that shows wider distribution with respect to the three diagram vertexes (Fig. 4).

The investigation of SOM distribution in the grain-size fractions (the "Soil organic matter content" section) showed a tendency for organic matter to concentrate in the finer fraction $(<75 \mu \mathrm{m})$. A possible explanation for this result may be an abundant presence of very small roots $(<75 \mu \mathrm{m})$ in the samples, with mean dimensions comparable with the size of finer inorganic fractions. Another explanation may be that SI and CL grains protect the finer SOM $(<75 \mu \mathrm{m})$ from further decomposition; previous studies (Schmidt and KögelKnabner 2002; Shang et al. 2014) reported that this fine SOM would accumulate in the voids of SI and CL, and in these empty spaces, it would be protected against further decomposition. Thus, the higher the abundance of finer inorganic fractions is, the higher the content of SOM, thus far explaining the positive correlation existing between the abundance of the finer $(<75 \mu \mathrm{m})$ inorganic fractions (i.e. silt and clay) and organic matter content.

Usually, as for the 2009 LUCAS database, 2-mm-sieved samples are analysed for SOM/SOC analysis, so we transformed the measured SOM values of this study to be expressed as a percentage of the sample fraction finer than $2 \mathrm{~mm}$ to compare the data. As shown in Fig. 5, the highest values of SOM have been detected at sites with CFS, CF and ST vegetation cover (excluding site number 15, which is classified as MD), 
Fig. 4 Surveyed sites represented in a ternary plot of grain-size distribution (with clay and silt combined) with different symbols representing different vegetation cover (according to the vegetation classification processed for this study, see the "Grain-size distribution and geo-hydrological parameters" section)

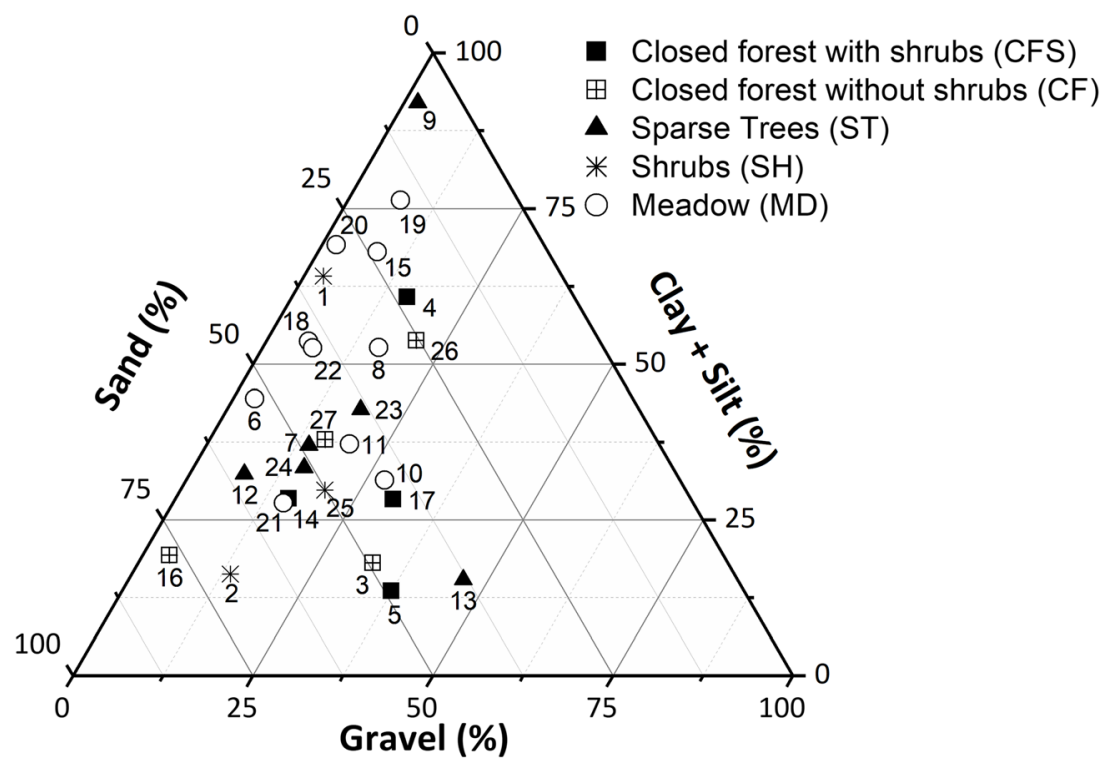

and lower SOM contents are generally associated with MD vegetation cover type. However, the MD class is the one with the largest range of variation in SOM values, which lie in an interval of $7.5 \%$. Indeed, both the highest and the lowest values of SOM belong to this vegetation class, while $\mathrm{CF}$ is the vegetation cover type with the smallest range of variation (1.4\%).

In every case, it is worth noting that we did not have an equal number of samples for every vegetation class, so that this could have affected the distribution of SOM contents among the different vegetation cover type classes. In the 2009 LUCAS database (Tóth et al. 2013), for the two climates that they consider for Tuscany, Mediterranean temperate and suboceanic (MTS) and Mediterranean mountainous (MM), the following values of SOC are reported: mean values of 22 and $25 \mathrm{~g} / \mathrm{kg}$ (12 and $18 \mathrm{~g} / \mathrm{kg}$ of standard deviation SD) for the MTS and MM climates, respectively, for "grasslands"; 36 and $25 \mathrm{~g} / \mathrm{kg}$ (SD 24 and $25 \mathrm{~g} / \mathrm{kg}$ ), respectively, for "shrublands"; and 36 and $40 \mathrm{~g} / \mathrm{kg}$ (SD 24 and $29 \mathrm{~g} / \mathrm{kg}$ ), respectively, for "woodlands". Considering the definitions of these vegetation classes adopted by the 2009 LUCAS database, "grasslands" and "woodlands" are comparable with the MD and SH classes of this study, while the "woodlands" class would contain CFS, $\mathrm{CF}$ and ST. Therefore, our findings are in line with what is found in the 2009 LUCAS database: the European project reported the highest values of organic carbon in the "woodlands" areas; in our study, the highest values of SOM were found in the CFS, CF and ST classes.

The distance from plants is another critical factor determining the root density and soil organic matter. To deepen that aspect, a focused sampling strategy should be developed that provides for the collection of multiple samples at planned distances from the plants. The procedure should be applied to the main species (or combination of those) at several sites and replicated multiple times. Then, the SOM contents should be compared with the actual number of roots of the surveyed volumes of soil. However, this experimentation is beyond the scope of the present study that is mainly focusing on the development of a new procedure to include root fragments in the SOM measurement and on the study of the relationships between SOM and geotechnical parameters.
Fig. 5 Soil organic matter (SOM) of samples with error bars and the vegetation cover of respective sites (vegetation classification processed for this study, see the "Grain-size distribution and geohydrological parameters" section)

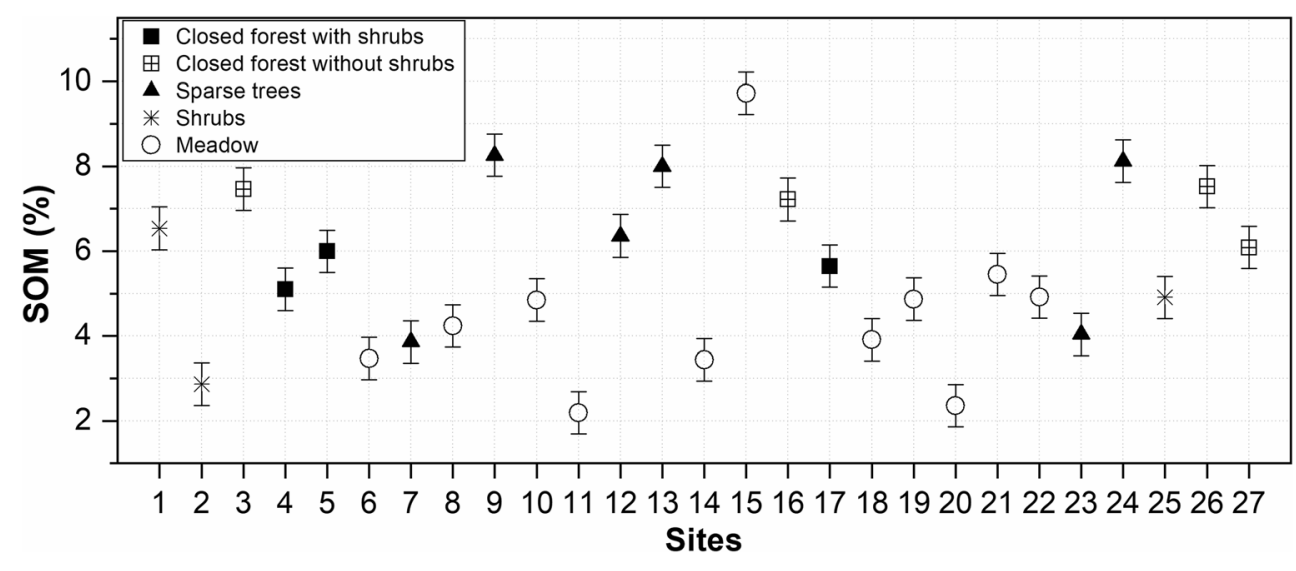




\section{SOM and mineral assemblage controls on the geotechnical parameters}

The SOM and mineralogical composition of samples can exert various degrees of control on the geotechnical properties of soils.

As a first step, the analysis for the presence and abundance of inorganic carbonates (i.e. calcite) in the samples was essential to exclude or not the influence of these minerals on the SOM measurements. Among the 10 samples with the higher contents of organic matter, carbonate minerals appeared in only one of these (\#15; Fig. 6d), while all the samples containing carbonate minerals had intermediate to low organic matter contents. These findings suggest that in our set of samples, carbonate minerals have had no influence on the SOM measurements. The non-contribution of inorganic carbonates to the measured organic matter is even more evident in Fig. 6a-c, where the high SOM contents (i.e. higher than 6\%) almost exclusively correspond to inorganic carbon-free samples. Interactions between soil parental material and climate conditions determine the mineral phases of the soils and the abundance of nutrient elements for plants. The characterization of soil mineralogical composition was hence significant to analyse the relationships between the soil characteristics and parameters considered in this study.

The most common mineralogical phases of the samples derive from the weathering of arenaceous, calcareous and marly bedrock (Barbieri 1981; Carnicelli et al. 1997; Certini et al. 2003) that are widespread in the Tuscan region. As well as, the presence of the uncommon phases of the samples is the result of the alteration of bedrock of less common mineralogical composition, such as metasedimentary rocks for haematite (accessory mineral), metamorphic rocks for chrysotile and prehnite (the latter as a result of chemical reaction with the metamorphic rock), evaporite rocks for gypsum and magmatic rocks for basanite. The presence of goethite in one site is likely attributable to the alteration and transport of mother rocks located elsewhere. Because most of the samples are quite similar in mineralogical composition, no significant relations between the mineral phases and the type of vegetation could be found.

To inspect the relations between the SOM and geohydrological properties of our sample set, the Pearson correlation index $(r)$ between those variables was calculated (Table 3). Before proceeding with the correlation analysis, the SOM contents and grain-size distributions are transformed to appropriately consider their compositional nature. As long as this kind of data is constituted by values representing a proportion of a whole (so they are constrained to a constant $\mathrm{k}$, equal to $100 \%$ in our case) and are never negative, they are defined "compositional", and common statistical approaches are not appropriate to treat them (Aitchison 1982). Considering this, "logit transformation" was applied to the SOM data, while for grain-size distributions, the "isometric log-ratio" or "ill transformation" (Egozcue et al. 2003) was chosen.
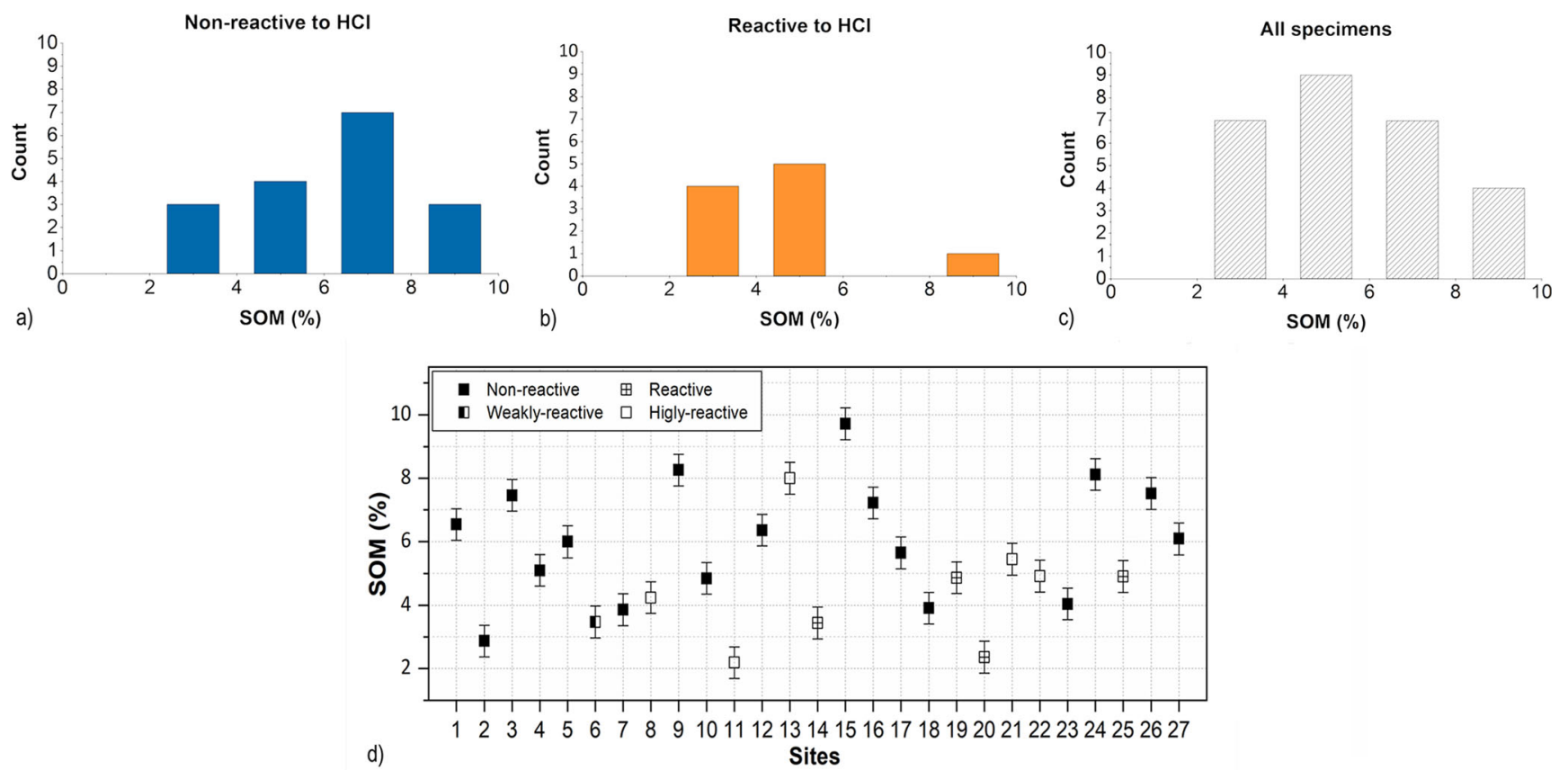

Fig. 6 a Histograms of the soil organic matter (SOM) in samples nonreactive to $\mathrm{HCl}$. b Histograms of the SOM in samples reactive to $\mathrm{HCl}$. c Histograms of the SOM in all specimens. d The SOM content of samples (the percentage of SOM with respect to the fraction smaller than $2 \mathrm{~mm}$ ) and reactivity to $\mathrm{HCl}$. The vertical bars represent the range of error for SOM evaluation 
Table 3 Pearson's correlation coefficient $(r)$ of the soil organic matter $(\mathrm{SOM})$ and grain-size distribution $\left(\mathrm{ilr}_{1}\right.$ and $\mathrm{ilr}_{2}$ ) of samples with respect to geotechnical properties. IP plasticity index, $\gamma_{d}$ dry unit weight, $\varphi^{\prime}$ effective internal friction angle, $\log K_{\text {Sat }}$ saturated hydraulic conductivity transformed by applying a $\log 10$ to the raw data; logit SOM is the logit transformation of SOM; ilr $r_{1}$ and ilr $_{2}$ are two different ilr transformations of the grain-size distribution

\begin{tabular}{ccccc}
\hline & $\mathrm{IP}(\%)$ & $\mathrm{\gamma d}_{\mathrm{d}}\left(\mathrm{kN} / \mathrm{m}^{3}\right)$ & $\log \mathrm{K}_{\mathrm{Sat}}$ & $\varphi^{\prime}\left({ }^{\circ}\right)$ \\
\hline logit SOM & - & -0.32 & 0.04 & 0.28 \\
$\operatorname{logit~SOM~}<2 \mathrm{~mm}$ & -0.34 & - & - & - \\
$\operatorname{ilr}_{1}$ & - & -0.16 & 0.09 & 0.32 \\
$\operatorname{ilr}_{2}$ & 0.61 & - & - & - \\
\hline
\end{tabular}

The logit transformation for SOM is as follows:

$\operatorname{logit}(\mathrm{SOM})=\ln \frac{\mathrm{SOM}}{(100-\mathrm{SOM})}$,

where $\ln$ represents the natural logarithm, and the SOM is expressed as the \% weight fraction of the whole sample, whose weight is normalized to $100 \%$. The ilr transformation was chosen since the transformed variables (the abundances of the four granulometric fractions GR, SA, SI and CL in our case) can be arranged to provide a simple interpretation of the variables themselves. Ilr-transformed data represent the relative variation in the two groups of parts in the form of "balances", which are a particular form of ilr coordinates that in our case are given by the following equations:

$\mathrm{ilr}_{1}=\frac{1}{\sqrt{6}} \cdot \ln \frac{G R \cdot S A}{S I \cdot C L}$,
$\mathrm{ilr}_{2}=\frac{1}{\sqrt{6}} \cdot \ln \frac{S I \cdot C L}{S A^{2}}$.

It is worth noting that the two chosen ilr balances are not part of the same binary partition scheme (i.e. they cannot be used as coordinates for a binary graph).

In Table 3, the correlation coefficients of the SOM and grain-size distribution with the geotechnical properties are shown. All the parameters involved in the correlation analysis can be described a Gaussian frequency distribution, since all of them passes the Shapiro-Wilk normality test $(p>0.05)$; the $\mathrm{K}_{\text {Sat }}$ passes the normality test only after the raw data are logtransformed (i.e. this parameter is describable with a lognormal distribution) so the correlation analysis is performed by using the $\log \mathrm{K}_{\text {Sat. }}$ In the interpretation of the Pearson index values, it is necessary to consider that such an index is not an appropriate descriptor of a dependency relation if the relation between the variables is non-linear, and that possible outliers can have a strong influence on the results. The plasticity index is measured on the fraction of samples finer than $0.425 \mathrm{~mm}$, so in the correlation analysis involving this parameter, the $\mathrm{ilr}_{2}$ transformation and the logit of the SOM in the fraction finer than $2 \mathrm{~mm}$ (SOM $<2 \mathrm{~mm})$ were considered. In the other cases (i.e. $\mathrm{X}_{\mathrm{d}}, \varphi^{\prime}$ and $\mathrm{K}_{\mathrm{Sat}}$ ), the il $\mathrm{r}_{1}$ transformation (which includes all grain-size fractions) and SOM in the whole sample were used instead since these parameters are measured on the whole sample. The moderately high correlation $(r=0.61)$ found between the $\mathrm{ilr}_{2}$ and plasticity index reflects the well-known effect of the clay fraction that increases the plasticity of the soil. The Pearson coefficient $(r=-0.34)$ related to SOM $<$ $2 \mathrm{~mm}$ vs IP expresses a moderate inverse correlation; therefore, as the organic matter increases, the soil plasticity decreases. This effect (comparable with the effect of sand in the soil that commonly decreases the plasticity) could be attributable to the small root fragments, to the particle organic matter of other shapes and origin and dissolved organic matter (particle organic matter is defined as soil organic matter between $0.045 \mathrm{~mm}$ and $2 \mathrm{~mm}$ in size, and dissolved organic matter is the fraction finer than $0.045 \mathrm{~mm}$; Thurman 1985 and Nebbioso and Piccolo 2013) or to all the previous factors (Buckman and Brady 1969; Malkawi et al. 1999). Regarding the dry unit weight, $r$ is equal to -0.16 when considering the relationship with the grain-size distribution $\left(\right.$ ilr $\left._{1}\right)$ and -0.32 for the SOM. The coefficient for the grain-size distribution could seem lower than expected since the dry unit weight certainly depends strongly on the grain-size distribution of a sample, but even the particle arrangement (i.e. the soil structure) in the sample strongly affects the unit weight, and this kind of information is not contained in the values of the four grain-size fractions. The negative correlation between the organic matter and unit weight of samples was expected having the organic matter a lower unit weight compared with the inorganic fractions. The moderate degree of the SOM- $\mathrm{X}_{d}$ couple highlights the importance of the organic matter evaluation every time the weight calculation of a bulk sediment is requested.

Regarding the relations with the effective friction angle measured in situ (Table 3), $r$ values suggest a positive moderate correlation (0.32) for the grain-size distribution (represented by the parameter ilr $r_{1}$ ) and a positive low-moderate correlation for the SOM (0.28). This relation between the grain-size distribution of soils and $\varphi^{\prime}$ reflect the fact that soils with a more abundant coarse fraction have higher friction angle values than those of finer soils (e.g. Carter and Bentley 1991). With regard to Pearson's coefficient of the SOM- $\varphi$ ' couple, the earlier hypothesis could also be made considering the results of the analysis of the SOM distribution with respect to the sample fractions (the "Soil organic matter content" section): since organic matter is more abundant in silt and clay fractions and because these fractions are inversely correlated with the friction angle, the positive low-moderate correlation could be due to the root contents in the samples. This finding suggests that root reinforcement could affect not only the cohesion but also the friction angle (in the literature, root reinforcement is commonly considered to affect only the 
cohesion parameter of the tensile strength; Gray 1974; Schmidt et al. 2001; Pollen 2007) and represents a first step in the corroboration of the SOM evaluation (with the operating modes adopted in this study) as an indirect method to estimate the root biomass in soils, but further insights are needed. It is worthwhile to mention here that the BST measures the shear strength on a certain volume of soil (depending on the lateral pressure exerted) that begins from the wall of the drilled borehole and extends towards the intact soil radially. A small part of the contribute of the roots to the shear strength is lost because the root network is interrupted. However, being undisturbed on all other sides of the surveyed volume, we believe that most part of that contribution remains measurable and sufficient to deepen the study of the relation between the SOM and the internal friction angle. Moreover, other procedures adopted to measure the contribution of the root to the shear strength of the soil, as in situ shear tests (e.g. Fan and Tsai 2016; Hubble et al. 2010; Wu and Watson 1998) using shear boxes, disturb the root network with a greater impact. The laboratory shear test (another very common procedure used by authors on rooted soil samples: Wu 1976; Waldron 1977; Terwilliger and Waldron 1991; Gray and Leiser 1982; Operstein and Frydman 2000; Pollen and Simon 2005; Giadrossich et al. 2010; Yildiz et al. 2015) performs the measures on even more disturbed samples. Indeed, other authors used the BST in field shear tests on rooted soil (Giadrossich et al. 2010). In addition, also the smallest organic matter particles, having very different chemical and physical features compared with the inorganic fractions, can have an influence on the measured friction angles.

The analysis of the relation between the $\log \mathrm{K}_{\text {Sat }}$ vs grainsize distribution (ilr $r_{1}$ ) and vs SOM returned very low values of Pearson's coefficient: 0.09 and -0.04 , respectively. For both the grain-size distribution and SOM, one reason for these low values could be that the soil sampling was optimized with regard to the BST test; therefore, samples were withdrawn around the bore for the shear strength test. The $\mathrm{K}_{\mathrm{Sat}}$ measurements were obtained with a kind of in situ test that consider a significatively larger volume (at least $1 \mathrm{~m}$ deep under the bore), with respect to the volume investigated while measuring $\varphi$ ' with the BST. Further details on the adopted experimental setup for in situ tests can be found in Tofani et al. (2017) and references therein. In addition, as also reported in Bicocchi et al. $(2016,2019)$ for the saturated hydraulic conductivity, $\mathrm{K}_{\text {Sat }}$ values for these samples are described by asymmetric ("skew") log-normal distribution characterized by the presence of outlier data. Indeed, a search for detecting possible outliers has been made, highlighting that many are the samples that show, relatively to the $\mathrm{K}_{\mathrm{Sat}}$, values extremely far from the centre of the log-normal distribution. Therefore, it was not possible to exclude these values from the correlation analysis without drastically reducing the data available, an operation that invalidates and compromises a priori the significance of the $r$ parameters, independently of the values found. Thus, considering its inner proprieties of high variances, $\mathrm{K}_{\mathrm{Sat}}$ can be hardly correlated with other variable with relative lower variances and greater symmetry in the frequency distribution curve.

\section{Conclusions}

Organic matter is a fundamental component of soil representing the major pool for carbon in the pedosphere. Even if soil organic matter (SOM) has very different features in terms of weight and physical-chemical behaviour compared with inorganic components, the evaluation of SOM is not a very common practice in soil characterization for geotechnical purposes.

In this study, we (1) identified and set up an efficient method to evaluate SOM contents (fragments of roots included) in soil samples, (2) measured variations in SOM in the selected samples of the hillslope deposits of Tuscany and (3) studied the relations of SOM with vegetation cover, mineralogical composition, grain-size distribution and geotechnical parameters (dry unit weight, effective friction angle, hydraulic conductivity and Atterberg limits).

The method we adopted in this study to measure the SOM contents (based on a traditional LOI procedure modified and adapted to our research aims) also allows us to measure an important fraction of the SOM that is usually lost during the analysis, i.e. the root fragments.

The range of variation in the SOM normalized to the bulk samples is $1.8-8.9 \%$ by weight in the study area. The organic matter of the superficial soils of Tuscany therefore represents a non-negligible fraction that should be considered when soil characterizations are carried out. The highest values of SOM were found at sites classified as "closed forest without shrubs" and "sparse trees", thus characterized by a more or less abundant presence of trees, whereas the sites with the lowest values of SOM are characterized by a cover of "meadow" without trees. Future investigations that envisage increasing the number of sites treated in the same way may eventually (1) provide further details on the relationships between the organic matter and vegetation in this study area and (2) allow insights into the result of higher SOM contents at sites with trees to determine whether the finding is due to the aboveground or belowground parts of plants (foliage and branches or roots, respectively). To use SOM evaluations as an indirect measure of root density, a research project on the topic can begin with the findings of this study; first, the most appropriate sampling strategy and the proportionality between the SOM values and root density when the plant species and significant environmental characteristics change should be determined.

Moderate correlations of the SOM were found with the plasticity index $(r=-0.34)$, dry unit weight $(r=-0.32)$ and 
internal effective friction angle $(r=0.28)$, whereas SOM contents appear to be not related to the hydraulic conductivity values $(r=0.09)$. The existence of correlations between the SOM and plasticity index and unit weight highlights that, in addition to the abundances of the inorganic fractions in the soils (i.e. gravel, sand, silt and clay), the organic fraction should also be carefully and systematically evaluated on soil samples for the geotechnical characterization of soils, since it comes out that organic matter is able to exercise a nonnegligible control on geotechnical parameters. The correlation of the SOM with the friction angle strongly suggests the need for future research on this topic to understand if roots or particles and dissolved organic matter are responsible because, in the literature, root reinforcement is commonly considered to affect the cohesion only in the tensile strength of rootreinforced soils.

Acknowledgements The authors wish to thank Michele D'Ambrosio and Carlo Tacconi for their contributions during the field surveys. We want to warmly thank Pietro Vannocci and Elena Pecchioni for their help in geotechnical and XRPD analyses in the laboratory, respectively. Deepest thanks go to Orlando Vaselli for his crucial advice when developing and testing the method for determining the organic matter content. The authors also extend their gratitude to two anonymous reviewers for their suggestions.

Open Access This article is licensed under a Creative Commons Attribution 4.0 International License, which permits use, sharing, adaptation, distribution and reproduction in any medium or format, as long as you give appropriate credit to the original author(s) and the source, provide a link to the Creative Commons licence, and indicate if changes were made. The images or other third party material in this article are included in the article's Creative Commons licence, unless indicated otherwise in a credit line to the material. If material is not included in the article's Creative Commons licence and your intended use is not permitted by statutory regulation or exceeds the permitted use, you will need to obtain permission directly from the copyright holder. To view a copy of this licence, visit http://creativecommons.org/licenses/by/4.0/.

\section{References}

Aitchison J (1982) The statistical analysis of compositional data (with discussion). J R Stat Soc B 44(2):139-177

Alvarez W, Cocozza T, Wezel FC (1974) Fragmentation of the Alpine orogenic belt by microplate dispersal. Nature 248(5446):309-314. https://doi.org/10.1038/248309a0

Amoozegar A (1989) Compact constant head permeameter for measuring saturated hydraulic conductivity of the vadose zone. Soil Sci Soc Am J 53:1356-1361. https://doi.org/10.2136/sssaj1989. 03615995005300050009x

Anderson CJ, Coutts MP, Ritchie RM, Campbell DJ (1989) Root extraction force measurements for Sitka spruce. Forestry 62:127-137. https://doi.org/10.1093/forestry/62.2.127

Associazione Geotecnica Italiana (1963) Nomenclatura Geotecnica e Classifica delle Terre. Geotecnica 4:275-286

ASTM D2217-85 (1998) Standard practice for wet preparation of soil samples for particle-size analysis and determination of soil constants (withdrawn 2007). ASTM International. West Conshohocken, PA https://doi.org/10.1520/D2217-85R98
ASTM D422-63e2 (2007) Standard test method for particle-size analysis of soils. ASTM International, West Conshohocken. https://doi.org/ 10.1520/D0422-63R07

ASTM D4318-10e1 (2010) Standard test methods for liquid limit, plastic limit, and plasticity index of soils. ASTM International, West Conshohocken. https://doi.org/10.1520/D4318-10

Barbieri M (1981) Problemi connessi con la geochimica dei minerali detritici e di alcuni minerali di neoformazione entro i sedimenti: significato della presenza in essi di particolari elementi chimici. Rend Soc Ital Mineral Petrol 37(2):881-912

Bartolini C (2003) When did the northern Apennine become a mountain chain? Quat Int 101-102:75-80. https://doi.org/10.1016/S10406182(02)00090-3

Bernoux M, Cerri CC, Neill C, de Moraces JFL (1998) The use of stable isotopes for estimating soil organic matter turnover rates. Geoderma 82:43-58. https://doi.org/10.1016/S0016-7061(97)00096-7

Bicocchi G, D'Ambrosio M, Vannocci P, Nocentini M, Tacconi-Stefanelli C, Masi EB, Carnicelli S, Tofani V, Catani F (2015) Preliminary assessment of the factors controlling the geotechnical and hydrological properties in the hillslope deposits of eastern Tuscany (Central Italy). In: IAMG 2015 Proceedings: 867-874

Bicocchi G, D’Ambrosio M, Rossi G, Rosi A, Tacconi-Stefanelli C, Segoni S, Nocentini M, Vannocci P, Tofani VN, Casagli, Catani F (2016) Geotechnical in situ measures to improve landslides forecasting models: a case study in Tuscany (Central Italy). Landslides and Engineered Slopes. Experience, Theory and Practice: Proceedings of the 12th International Symposium on Landslides (Napoli, Italy, 12-19 June 2016), CRC Press, 419-424

Bicocchi G, Tofani V, D’Ambrosio M, Tacconi-Stefanelli C, Vannocci P, Casagli N, Lavorini G, Trevisani M, Catani F (2019) Geotechnical and hydrological characterization of hillslope deposits for regional landslide prediction modelling. Bull Eng Geol Environ 78:48754891. https://doi.org/10.1007/s10064-018-01449-z

Bischetti GB, Chiaradia EA, Simonato T, Speziali B, Vitali B, Vullo P, Zocco A (2005) Root strength and root area ratio of forest species in Lombardy (northern Italy). Plant Soil 278(1):11-22. https://doi.org/ 10.1007/978-1-4020-5593-5 4

Bischetti GB, Chiaradia EA, Epis T, Morlotti E (2009) Root cohesion of forest species in the Italian Alps. Plant Soil 324(1):71-89. https:// doi.org/10.1007/s11104-009-9941-0

Böhm W (1979) Methods of studying root systems. Ecol Stud 33, 188 pp. https://doi.org/10.1007/978-3-642-67282-8

Bortolotti V (1992) Guida geologica. Vol. 4: Appennino tosco-emiliano, Be-Ma, Milano

Brady N, Weil RR (1999) The nature and properties of soils, 12th edn. Prentice Hall, Upper Saddle River, New Jersey

Buckman HO, Brady NC (1969) The nature and properties of soils. The Macmillan, London

Burylo M, Hudek C, Rey F (2011) Soil reinforcement by the roots of six dominant species on eroded mountainous marly slopes (Southern Alps, France). Catena 84:70-78. https://doi.org/10.1016/j.catena. 2010.09.007

Cambardella CA, Gajda AM, Doran JW, Wienhold BJ, Kettler TA, Lal R (2011) Estimation of particulate and total organic matter by weight loss-on-ignition. In: Lal R, Kimble JM, Follett RF, Stewart BA (eds) Assessment methods for soil carbon, 1st edn. CRC Press, Boca Raton, pp 349-359

Carmignani L, Kligfield R (1990) Crustal extension in the Northern Apennines: the transition from compression to extension in the Alpi Apuane core complex. Tectonics 9(6):1275-1303. https://doi. org/10.1029/TC009i006p01275

Carnicelli S, Mirabella A, Cecchini G, Sanesi G (1997) Weathering of chlorite to a low-charge expandable mineral in a spodsol in the Apennine mountains, Italy. Clay Miner 45(1):28-41. https://doi. org/10.1346/CCMN.1997.0450104 
Carter M, Bentley S (1991) Correlations of soil properties. Pentech Press Ltd, London, p 130

Certini G, Hillier S, McMurray E, Edwards AC (2003) Weathering of sandstone clasts in a forest soil in Tuscany (Italy). Geoderma 116(34):357-372

CLC (2012) Land Monitoring Service. https://land.copernicus.eu/paneuropean/corine-land-cover/clc-2012?tab=download. Accessed 3 September 2018

Convertino M, Troccoli A, Catani F (2013) Detecting fingerprints of landslide drivers: a MaxEnt model. J Geophys Res Earth Surf 118(3):1367-1386

Costa C, Dwyer LM, Hamilton RI, Hamel C, Nantais L, Smith DL (2000) A sampling method for measurement of large root systems with scanner-based image analysis. Agron J 92(4):621-627. https://doi. org/10.2134/agronj2000.924621x

De Baets S, Poesen J, Reubens B, Wemans K, De Baerdemaeker J, Muys B (2008) Root tensile strength and root distribution of typical Mediterranean plant species and their contribution to soil shear strength. Plant Soil 305:207-226. https://doi.org/10.1007/s11104008-9553-0

Dietrich WE, McKean J, Bellugi D, Perron T (2007) The prediction of shallow landslide location and size using a multidimensional landslide analysis in a digital terrain model. In: Chen CL, Major JJ (eds) Proceedings of the Fourth International Conference on Debris-Flow Hazards Mitigation: Mechanics, Prediction, and Assessment (DFHM-4); Chengdu, China, September 10-13, 2007. IOS Press, Amsterdam. $12 \mathrm{p}$

Ding G, Novak JM, Amarasiriwardena D, Hunt PG, Xing B (2002) Soil organic matter characteristics as affected by tillage management. Soil Sci Soc Am J 66(2):421-429. https://doi.org/10.2136/ sssaj2002.0421

Dowdy RH, Smucker AJM, Dolan MS, Ferguson JC (1998) Automated image analyses for separating plant roots from soil debris elutrated from soil cores. Plant Soil 200(1):91-94. https://doi.org/10.1023/A: 1004370627069

Egli M, Mirabella A, Sartori G (2008) The role of climate and vegetation in weathering and clay mineral formation in late Quaternary soils of the Swiss and Italian Alps. Geomorphology 102:307-324. https:// doi.org/10.1016/j.geomorph.2008.04.001

Egozcue JJ, Pawlowsky-Glahn V, Mateu-Figueras G, Barcelo-Vidal C (2003) Isometric logratio transformations for compositional data analysis. Math Geol 35(3):279-300. https://doi.org/10.1023/A: 1023818214614

Ellenberg H (1965) Tentative physiognomic ecological classification of plant formations of the earth. Ber Geobot Inst ETH Stiftg, Rübel, Zürich 37:21-55

Elter P, Giglia G, Tongiorgi M, Trevisan L (1975) Tensional and compressional areas in the recent (Tortonian to present) evolution of the northern Apennines. Boll Geofis Teor Appl 17:3-19

Fan CC, Tsai MH (2016) Spatial distribution of plant root forces in rootpermeated soils subject to shear. Soil Tillage Res 156:1-15

Fatichi S, Caporali E (2009) A comprehensive analysis of changes in precipitation regime in Tuscany. Int J Climatol 29(139):18831893. https://doi.org/10.1002/joc.1921

Fisler DK, Cygan RT (1998) Cation diffusion in calcite: determining closure temperatures and the thermal history for the Allan Hills 84001 meteorite. Meteorit Planet Sci 33(4):785-789

FRA 2015 Terms and Definitions, Forest Resources Assessment (2012). Working Paper 180, Food and Agriculture Organization of the United Nations, Rome

Franklin AF, Orozco LF, Semrau R (1973) Compaction of slightly organic soils. J Soil Mech Div-Asce 99:541-557

Gan JKM, Fredlund DG, Rahardjo H (1988) Determination of the shear strength parameters of an unsaturated soil using the direct shear test. Can Geotech J 25(3):500-510
Genet M, Stokes A, Salin F, Mickovski SB, Fourcaud T, Dumail JF, Van Beek R (2005) The influence of cellulose content on tensile strength in tree roots. Plant Soil 278(1-2):1-9. https://doi.org/10.1007/ s11104-005-8768-6

Genet M, Kokutse N, Stokes A, Fourcaud T, Cai XH, Ji JN, Mickovski S (2008) Root reinforcement in plantations of Cryptomeria japonica D. Don: effect of tree age and stand structure on slope stability. For Ecol Manag 256:1517-1526. https://doi.org/10.1016/j.foreco.2008. 05.050

Genet M, Li M, Luo T, Fourcaud T, Clément-Vidal A, Stokes A (2010) Linking carbon supply to root cell-wall chemistry and mechanics at high altitudes in Abies georgei. Ann Bot London 107(2):311-320. https://doi.org/10.1093/aob/mcq237

Giadrossich F, Guastini E, Preti F, Vannocci P (2010) Experimental methodologies for the direct shear tests on soils reinforced by roots. Geol J Tech Environ Geol 4:67-76

Gray DH (1974) Reinforcement and stabilization of soil by vegetation. J Geotech Geoenviron 100(GT6):695-699

Gray DH, Leiser AT (1982) Biotechnical slope protection and erosion control. Van Nostrand Reinhold Co., New York, p 267

Gray DH, Sotir RB (1996) Biotechnical and soil bioengineering slope stabilization: a practical guide for erosion control, John Wiley \& Sons

Grayston SJ, Vaughan D, Jones D (1997) Rhizosphere carbon flow in trees, in comparison with annual plants: the importance of root exudation and its impact on microbial activity and nutrient availability. Appl Soil Ecol 5(1):29-56. https://doi.org/10.1016/S0929-1393(96) 00126-6

Hales TC, Miniat CF (2017) Soil moisture causes dynamic adjustments to root reinforcement that reduce slope stability. Earth Surf Process Landf 42(5):803-813 https://doi.org/10.1002/esp.4039

Hales TC, Ford CR, Hwang T, Vose JM, Band LE (2009) Topographic and ecologic controls on root reinforcement. J Geophys Res Earth 114(F03013):1-17. https://doi.org/10.1029/2008JF001168

Hales TC, Cole-Hawthorne C, Lovell L, Evans SL (2013) Assessing the accuracy of simple field based root strength measurements. Plant Soil 372(1-2):553-565. https://doi.org/10.1007/s11104-013-1765-2

Hess D, Tasa DG (2016) McKnight's physical geography: a landscape appreciation, 12th edn. Pearson

Holtz RD, Krizek RJ (1970) Properties of slightly organic top soils. J Construct Div ASCE 96:29-43

Hubble TCT, Docker BB, Rutherfurd ID (2010) The role of riparian trees in maintaining riverbank stability: a review of Australian experience and practice. Ecol Eng 36(3):292-304

Jensen V, Andersen KJ, Krysell M (2003) Desk study on total organic carbon (TOC). Eurofins A/S Horizontal, pp 2-17

Jia N, Mitani Y, Xie M, Djamaluddin I (2012) Shallow landslide hazard assessment using a three-dimensional deterministic model in a mountainous area. Comput Geotech 458:1-10. https://doi.org/10. 1016/j.compgeo.2012.04.007

Kligfield R (1979) The northern Apennines as a collisional orogen. Am J Sci 279(6):676-691

Krull ES, Skjemstad JO, Baldock JA (2004) Functions of soil organic matter and the effect on soil properties. GRDC Project No CSO 00029, Grains Research and Development Corporation, Kingston, ACT, Canberra

Lohmann U, Sausen R, Bengtsson L, Cubasch U, Perlwitz J, Roeckner E (1993) The Köppen climate classification as a diagnostic tool for general circulation models. Clim Res 3:177-193. https://doi.org/10. 3354/cr003177

Lutenegger AJ, Hallberg GR (1981) Borehole shear test in geotechnical investigations. Laboratory shear strength of soil, ASTM International, pp 566-578

Magdoff FR, Tabatabai MA, Hanlon EA (1996) Soil organic matter: analysis and interpretation. SSSA Special Publication 46 
Malkawi AIH, Alawneh AS, Abu-Safaqah OT (1999) Effects of organic matter on the physical and the physicochemical properties of an illitic soil. Appl Clay Sci 14(5-6):257-278. https://doi.org/10. 1016/S0169-1317(99)00003-4

Montgomery DR, Schmidt KM, Greenberg HM, Dietrich WE (2000) Forest clearing and regional landsliding. Geology 28(4):311-314. https://doi.org/10.1130/0091-7613(2000)28<311:FCARL>2.0.CO; 2

Nebbioso A, Piccolo A (2013) Molecular characterization of dissolved organic matter (DOM): a critical review. Anal Bioanal Chem 405(1): 109-124. https://doi.org/10.1007/s00216-012-6363-2

$\mathrm{Ng}$ CWW, Leung AK (2012) In-situ and laboratory investigations of stress-dependent permeability function and SDSWCC from an unsaturated soil slope. Geotech Eng 43(1):26-39

Ng CWW, Pang YW (2011) Experimental investigations of the soil-water characteristics of a volcanic soil. Can Geotech J 37(6):1252-1264. https://doi.org/10.1139/cgj-37-6-1252

Norris JE (2005) Root reinforcement by hawthorn and oak roots on a highway cut-slope in southern England. Plant Soil 278:43-53. https://doi.org/10.1007/s11104-005-1301-0

Odell RT, Thornburn TH, Mckenzie LJ (1960) Relationship of Atterberg limits to some other properties of Illinois soils. Soil Sci Soc Am J 24(4):297-300

Operstein V, Frydman S (2000) The influence of vegetation on soil strength. Proc Inst Civ Eng Ground Improv 4(2):81-89

Owens PR, Rutledge EM (2005) Morphology. In: Encyclopaedia of Soils in the Environment, Elsevier, pp 511-520. https://doi.org/10.1016/ B0-12-348530-4/00002-3

Pan WB, Bolton RP, Lundquist EJ, Hiller LK (1998) Portable rhizotron and color scanner system for monitoring root development. Plant Soil 200(1):107-112. https://doi.org/10.1023/A:1004277118087

Pollen N (2007) Temporal and spatial variability in root reinforcement of streambanks: accounting for soil shear strength and moisture. Catena 69(3):197-205. https://doi.org/10.1016/j.catena.2006.05. 004

Pollen N, Simon A (2005) Estimating the mechanical effects of riparian vegetation on stream bank stability using a fiber bundle model. Water Resour Res 41(7)

Pribyl DW (2010) A critical review of the conventional SOC to SOM conversion factor. Geoderma 156(3-4):75-83. https://doi.org/10. 1016/j.geoderma.2010.02.003

Rapetti F (2004) Tendenze attuali del clima termico invernale ed estivo a Lucca (1929-2003). Atti Soc Tosc Sc Nat Ser A 109:85-89

Rapetti F, Vittorini S (1986) L'episodio di gelo del gennaio 1985 in Toscana. Con particolare riguardo alla bassa valle dell'Arno. Rivista Geografica Italiana 93(4):437-447

Rasmussen PE, Collins HP (1991) Long-term impacts of tillage, fertilizer, and crop residue on soil organic matter in temperate semiarid regions. Adv Agron 45:93-134. https://doi.org/10.1016/S00652113(08)60039-5

Riestenberg MM (1994) Anchoring of thin colluvium by roots of sugar maple and white ash on hillslopes in Cincinnati. US Geol Surv Bull 2059-E:1-25

Romero E, Gens A, Lloret A (1999) Water permeability, water retention and microstructure of unsaturated compacted Boom clay. Eng Geol 54(1-2):117-112. https://doi.org/10.1016/S0013-7952(99)00067-8

Rosi A, Tofani V, Tanteri L, Tacconi Stefanelli C, Agostini A, Catani F, Casagli N (2017) The new landslide inventory of Tuscany (Italy) updated with PS-InSAR: geomorphological features and landslide distribution. Landslide 15(1):5-19. https://doi.org/10.1007/s10346017-0861-4

Salehi MH, Beni OH, Harchegani HB, Borujeni IE, Motaghian HR (2011) Refining soil organic matter determination by loss-on-ignition. Pedosphere 21(4):473-482. https://doi.org/10.1016/S10020160(11)60149-5
Scanlan C A, Hinz C (2010) Insights into the processes and effects of root-induced changes to soil hydraulic properties. In: 2010 19th World Congress of Soil Science, Soil Solutions for a Changing World, pp 1-6

Schmidt NO (1965) A study of the isolation of organic matter as a variable affecting engineering properties of soil. Dissertation, University of Illinois at Urbana

Schmidt MWI, Kögel-Knabner I (2002) Organic matter in particle-size fractions from A and B horizons of a Haplic Alisol. Eur J Soil Sci 53(3):383-391. https://doi.org/10.1046/j.1365-2389.2002.00460.x

Schmidt KM, Roering JJ, Stock JD, Dietrich WE, Montgomery DR, Schaub T (2001) The variability of root cohesion as an influence on shallow landslide susceptibility in the Oregon Coast Range. Can Geotech J 38(5):995-1024. https://doi.org/10.1139/cgj-38-5-995

Scholl P, Leitner D, Kammerer G, Loiskandl W, Kaul H-P, Bodner G (2014) Root induced changes of effective 1D hydraulic properties in a soil column. Plant Soil 381(1-2):193-213. https://doi.org/10. 1007/s11104-014-2121-x

Schulte EE (1995) Recommended soil organic matter tests, recommended soil testing procedures for the north eastern USA. Northeastern Reg Publ 493:52-60

Shang S, Jiang P, Chang SX, Song Z, Liu J, Sun L (2014) Soil organic carbon in particle size and density fractionations under four forest vegetation-land use types in subtropical China. Forests. 5(6):13911408. https://doi.org/10.3390/f5061391

Subedi KD, Ma BL, Liang BC (2006) New method to estimate root biomass in soil through root-derived carbon. Soil Biol Biochem 38(8):2212-2218. https://doi.org/10.1016/j.soilbio.2006.01.027

Taleisnik E, Peyrano G, Cordoba A, Arias C (1999) Water retention capacity in root segments differing in the degree of exodermis development. Ann Bot (Lond) 83(1):19-27. https://doi.org/10.1006/ anbo.1998.0781

Terwilliger VJ, Waldron LJ (1991) Effects of root reinforcement on soilslip patterns in the transverse ranges of southern California. Geol Soc Am Bull 103(6):775-785

Thurman EM (1985) Organic geochemistry of natural waters. In: Developments in Biogeochemistry, vol 2. Springer, Netherlands. https://doi.org/10.1007/978-94-009-5095-5

Tofani V, Bicocchi G, Rossi G, Segoni S, D’Ambrosio M, Casagli N, Catani F (2017) Soil characterization for shallow landslides modeling: a case study in the Northern Apennines (Central Italy). Landslides 14:755-770. https://doi.org/10.1007/s10346-017-08098

Tosi M (2007) Root tensile strength relationships and their slope stability implications of three shrub species in the Northern Apennines (Italy). Geomorphology 87(4):268-283. https://doi.org/10.1016/j. geomorph.2006.09.019

Tóth G, Montanarella L, Stolbovoy V, Máté F, Bódis K, Jones A, Panagos P, Van Liedekerke M (2008) Soils of the European union, JRC Scientific and Technical Reports, Office for Official Publications of the European Communities, Luxembourg

Tóth G, Jones A, Montanarella L (2013) LUCAS topsoil survey methodoloy, data and results, JRC Technical Reports EUR 26102, Luxembourg, Publications Office of the European Union

Traoré O, Groleau-Renaud V, Plantureux S, Tubeileh A, Boeuf-Tremblay $\mathrm{V}$ (2000) Effect of root mucilage and modelled root exudates on soil structure. Eur J Soil Sci 51(4):575-581. https://doi.org/10.1111/j. 1365-2389.2000.00348.x

Trigila A, Frattini P, Casagli N, Catani F, Crosta G, Esposito C, Iadanza C, Lagomarsino D, Scarascia Mugnozza G, Segoni S, Spizzichino D, Tofani V, Lari S (2013) Landslide susceptibility mapping at national scale: the Italian case study. In: Landslide science and practice. Springer, Berlin, Heidelberg, pp 287-295

Vai GB (2001) Structure and stratigraphy: an overview. In: Anatomy of an orogen: the Apennines and adjacent Mediterranean basins. Springer, Dordrecht, pp 15-31 
Wagner AA (1957) The use of the unified soil classification system by the Bureau of Reclamation. Proc 4th Intern Conf Soil Mech Found Eng London 1:125-134

Waldron LJ (1977) The shear resistance of root-permeated homogeneous and stratified soil. Soil Sci Soc Am J 41(5):843-849

Wu TH (1976) Investigations of landslides on Prince of Wales Island. Geotechnical engineering report 5. Civil Engineering Department, Ohio State University, Columbus, Ohio, USA
Wu TH, Watson A (1998) In situ shear tests of soil blocks with roots. Can Geotech J 35(4):579-590

Yildiz A, Askarinejad A, Graf F, Rickli C, Springman SM (2015) Effects of roots and mycorrhizal fungi on the stability of slopes. Geotechn Eng Infrastruct Dev 2015:1693-1698

Zhang C, Chen L, Jiang J, Zhou S (2012) Effects of gauge length and strain rate on the tensile strength of tree roots. Trees 26(5):15771584. https://doi.org/10.1007/s00468-012-0732-5 